\title{
Modeling the Risk of Entry, Establishment, Spread, Containment, and Economic Impact of Tilletia indica, the Cause of Karnal Bunt of Wheat, Using an Australian Context
}

\author{
Chris D. Stansbury, Simon J. McKirdy, Art J. Diggle, and Ian T. Riley
}

First author: Department of Agriculture Western Australia, Bunbury District Office, P.O. Box 1231, Bunbury 6231 Western Australia, Australia; second and third authors: Department of Agriculture Western Australia, South Perth Office, Locked Bag No. 4, Bentley Delivery Centre 6983 Western Australia, Australia; and fourth author: Applied and Molecular Ecology, University of Adelaide, Waite Campus, PMB1, Glen Osmond 5064 South Australia, Australia. Accepted for publication 24 October 2001.

\begin{abstract}
Stansbury, C. D., McKirdy, S. J., Diggle, A. J., and Riley, I. T. 2002. Modeling the risk of entry, establishment, spread, containment, and economic impact of Tilletia indica, the cause of Karnal bunt of wheat, using an Australian context. Phytopathology 92:321-331.

Modeling techniques were developed to quantify the probability of Tilletia indica entering and establishing in Western Australia (WA), and to simulate spread, containment, and the economic impact of the pathogen. Entry of $T$. indica is most likely to occur through imports of bulk grain or fertilizer $(0.023 \pm 0.017$ entries per year and approximately $0.009 \pm 0.009$ establishments per year). Entry may also occur through straw goods, new or second-hand agricultural machinery, and on personal effects of travelers who have visited regions with infected plants. The com-
\end{abstract}

ABSTRACT

Australia, because of its geographic isolation, is free of many plant pests and diseases of economic importance. One such disease is Karnal bunt of wheat (Triticum aestivum, T. dicoccum, T. turgidum [durum wheat], and triticale [wheat $\times$ rye, $\times$ Triticosecale]), caused by the fungus Tilletia indica. T. indica was originally described from Karnal, Haryana, India in 1930 (14). It is largely confined to the Middle East and is recorded in Afghanistan, Iran, Iraq, Lebanon, Nepal, and Pakistan (15). It has also been recorded in Mexico in 1972 (9), in southern wheat-growing regions in the United States in 1996 (3), and in the Northern Cape Province, South Africa, in 2000 (8).

Karnal bunt has minimal impact on crop yield $(3,15)$ but is considered a disease of political and quarantine importance, and is used as a non-tariff trade barrier (2). This is confirmed by recent research on the economic impact of Karnal bunt in Mexico $(4,5)$ and an Australia analysis that suggests up to $70 \%$ of costs of the disease can be attributed to a loss in export markets (15).

The origins, life cycle, epidemiology, and molecular detection of $T$. indica are now well known $(17,23)$, and the effects of environmental conditions on its survival and growth have been determined under controlled conditions (21). Climatic models have also been developed to simulate environmental conditions suitable for development of the disease in India $(12,13)$. Since the discovery of the pathogen in the United States, climate models have been used to simulate potential establishment and spread of Karnal bunt in the Imperial Valley (11) and Pacific Northwest (22) in the United States, the United Kingdom, the European Union

Corresponding author: C. Stansbury; E-mail address: cstansbury@agric.wa.gov.au

Publication no. P-2002-0124-01R

(C) 2002 The American Phytopathological Society bined probability of entry and establishment of $T$. indica, for all pathways of entry, is about one entry every 25 years and one establishment every 67 years. Alternatively, sensitivity analysis does show that increases in quarantine funding can reduce the probability of entry to about one entry every 50 years and less than one establishment every 100 years. T. indica is spread efficiently through contaminated farm machinery, seed and soil, rain, air currents, and animals. Depending on the rate of spread of the pathogen and the amount of resources allocated for detection, the time until first detection could range from 4 to 11 years and the economic impact could range from 8 to $24 \%$ of the total value of wheat production in WA.

Additional keywords: area freedom, import risk analysis, quantitative risk assessment, quarantine.

(20), South Africa (25), and in southern wheat-growing regions of Australia (15,24).

Australia has long established trade links in agricultural products with countries where Karnal bunt occurs, including India, Iran, Mexico, Pakistan, and the United States. For Australia to protect its wheat industries from trade restrictions that may result from a Karnal bunt outbreak (18), measures need to be implemented to ensure that the risk (expected loss) is acceptably low. A zero risk policy is unattainable because all movement into Australia would cease. Therefore, measures put in place by Australia must be based either on a relevant international standard, guideline, or recommendation, or upon an appropriate scientific risk analysis.

Since the discovery of $T$. indica in southern United States in 1996, its importance as a quarantine pest has been questioned. Research in Australia has concentrated on the identification of potential pathways for entry of $T$. indica $(15,16)$, without any attempt to estimate the probabilities of entry and establishment. There has been no attempt to integrate models that predict climatic suitability for the pathogen with processes such as disease spread, containment, and economic impact. The aim of this paper was to develop two risk assessment models for $T$. indica using the computer modeling software STELLA (High Performance Systems Inc., Hanover, NH). The first model attempts to quantify the risks and probabilities associated with pathogen entry and establishment. The second model estimates potential spread and the costs associated with control and management of the disease.

The pest risk analysis (PRA) area used was the wheatbelt region of Western Australia (WA), which currently produces about one third of Australia's 5.5 million ton annual production of wheat (Australian Bureau of Statistics, Agricultural Census, 1998 to 1999). Given that over $80 \%$ of WA wheat harvest is exported, it is 
clear that should WA lose its Karnal bunt area freedom status, the impact on wheat exports and other agricultural commodities could be substantial.

Through sensitivity analysis, both models will provide useful tools for making risk management decisions on the allocation of resources and the effectiveness of quarantine and containment strategies. It will also be possible to apply the models to assess the risk and impact of other important plant diseases, animal pests, and weed species.

\section{MATERIALS AND METHODS}

Model 1-Risk of pathogen entry and establishment. The first model incorporates two processes. First, the estimation of the probability of entry of $T$. indica. Given that the pathogen is present outside the PRA area, there is a probability of it entering the area, which depends on the number of pathways for entry and increases according to the amount of trade with countries where the disease occurs. Entry is also dependent on the probability of the pathogen being detected in contaminated imports by quarantine inspectors. The likelihood of establishment depends on the proportion of contaminated goods missed by quarantine that are transported to wheat growing shires and on whether or not contaminated produce successfully reaches and infects a susceptible host.

Estimates for input variables that drive the model were determined from Australian Quarantine and Inspection Service (AQIS) databases (Table 1). Where data were not available, or the value of input variables was uncertain, estimates were made using the best available data or expert judgment. For example, the proportion of grain imports that were contaminated but not intercepted by quarantine $\left(p_{m}\right)$ was estimated to be approximately one for every 100 imports that were rejected due to contamination. Estimates for the proportion of contaminated imports that went to wheat growing shires $\left(p_{t}\right)$ and the proportion that resulted in successful infection of the host plant $\left(p_{c}\right)$ for each pathway were estimated using expert opinion (Table 1).

Process 1-Pathogen entry. Pathogen entry refers to $T$. indica arriving at a port (sea or air) in WA, or by road from the eastern states of Australia (all of Australia is currently free of the pathogen). Entry of $T$. indica may occur in wheat seed for planting, in bulk grain imports contaminated with infected wheat, in wheat as a contaminant in herbs or other seed for sowing, in fertilizer transported in contaminated containers, on straw goods or packing material, on new or second-hand agricultural machinery contaminated with wheat, on personal effects of travelers who have had contact with infected crops or contaminated produce, on seed imported for plant breeding, and through mail order $(15,16)$. It is recognized that the pathogen could be introduced on either of these pathway, but due to the unavailability of data only four pathways have been included in the model framework. They are (i) straw goods or packing material, (ii) bulk grain or fertilizer, (iii) new or second-hand agricultural machinery contaminated with wheat, and (iv) personal effects of travelers who have had contact with infected crops or contaminated produce. Although it is possible that entry of a small number of spores could result in establishment of the pathogen (15), the inoculum threshold is not known.

Implementation. Given that the disease is present outside the PRA $\left(D_{p}\right)$, the number of successful entries $(I)$ for a vector at each time interval is chosen from $(\sim)$ a Poisson distribution:

$$
I \sim \text { Poisson }\left(n_{i} \cdot p_{i} \cdot p_{m}\right)
$$

where $n_{i}=$ the number of imports per year from a region where $T$. indica is known to occur, $p_{i}=$ the proportion of those imported goods that are contaminated, and $p_{m}=$ the proportion of contaminated goods not intercepted by quarantine inspection.
The Poisson distribution was chosen because it is ideal for modeling the number of events that occur per unit of time and for its properties of homogeneity and independence; i.e., the probability of an entry event occurring per unit of time remains constant and does not speed up or slow down, and each entry event is independent from any other (10). The Poisson process is only suitable assuming quarantine management decisions do not change the likelihood of future detection after the first detection of the pathogen (26).

The process is repeated for all four pathways for pathogen entry. Presence of the pathogen outside the PRA area is considered constant in this case, but it can be a random or seasonal factor depending on the disease and pathway of incursion. Table 1 lists the values for the above variables for each potential pathway of entry.

Process 2-Pathogen establishment. Second, after the likelihood of entry has been determined, the probabilities of $T$. indica establishment are incorporated. For every successful entry, there is a chance that the pathogen will establish. The probability of establishment varies depending on (i) the pathway, (ii) the number of successful entries ( $I$ in process 1 ), (iii) whether or not it is transported to a farm, (iv) the availability of a host plant, and (v) the climatic suitability of an area. For example, a pathogen that enters via second-hand farm machinery that goes straight to a farm that produces the host crop will have a higher probability of establishment compared with contaminated straw products used for domestic purposes. It is also possible for the pathogen to be introduced with a viable host plant seed. For instance, lentil (Lens culinaris Medik) or canola (Brassica napus L.) seed imported for planting could contain undetected contaminated wheat seeds or $T$. indica spores.

Implementation. The probability of at least one establishment $(E)$ is calculated using a binomial function:

$$
E=1-\left[1-\left(p_{t} \cdot p_{c}\right)\right]^{\wedge I}
$$

where $I=$ the number of successful entries in a year as described using equation $1, p_{t}=$ the proportion of contaminated imports transported to farms producing the host crop, and $p_{c}=$ the proportion of those contaminated imports that result in establishment.

The binomial function was chosen because it is ideal for describing a system where there are a definable number of entry events $(I)$, a probability of success of establishment $\left(p_{t} \cdot p_{c}\right)$, and a consequent number of successful establishments $(E)(26)$. The assumption is that all entries for a specific pathway are independent. Each entry event has the same probability of success as the entry before it, regardless of the outcome of the previous entry event. The cumulative number of establishment events $\left(E_{c}\right)$ for $T$. indica during a period is calculated by repeating the above process for each potential pathway of entry (Table 1).

Both the binomial and Poisson processes used in model 1 form a large part of the structure of animal and plant import risk analyses (26). However, in many cases hard data is not available for calculating probability values that drive the model processes. Consideration needs to be given to the fact that the model deals with anticipated risks, which are intrinsically hypothetical. Importantly, sensitivity analysis can be used to determine threshold probabilities that must not be exceeded in order to achieve a minimum level of risk.

Model 2-Pathogen spread, detection, containment, and economic impact. The second model incorporates pathogen spread, detection, and containment and calculates the economic impact of the disease. Spread of $T$. indica can occur efficiently through the movement of contaminated farm machinery, seed for sowing, soil, and by rain splash. Spores can also spread over long distances in air currents and with movement of livestock and manure after passage through the digestive tracts of animals. The area of infected crop increases at a rate related to the relative 
climatic suitability of the region, the current area of infected crop, and the size of the host crop (carrying capacity of the environment). Once the disease has established, there is a probability of it being detected. It is assumed that it can either be detected by a farmer, agronomist, or grain analyst during routine inspection of grain. It is also assumed that when a disease outbreak is detected it is successfully contained. Containment implies that all viable propagules of the pathogen are destroyed or quarantined such that they no longer contribute to spread. This could include eliminating all host plants from the crop rotation or leaving the area fallow for a period longer than the spores are known to remain viable in soil. Detection and containment are dependent on the availability of resources for the purpose. The final model process estimates the total cost of the disease outbreak to the industry.

Process 3-Pathogen spread. The initial assumption for the spread model is that the disease has already established in one shire in WA (category 1 shire). A shire is a local government area (average size of shires included in this study was 76,000 ha, ranging from 21,000 to 135,000 ha). The category 1 shire is surrounded by a number of bordering shires (category 2 shires) that collectively are surrounded by all remaining shires within the wheatbelt of WA (category 3 shires) (Fig. 1). Spread is simulated by the model following the establishment of $T$. indica in the category 1 shire. The chance of spread into a category 2 shire increases as the area of infected crop in the category 1 shire increases. Evidence collected in the United States suggests that long-distance spread of $T$. indica is rare and that localized spread aided by movement of people, seed, and machinery is most likely $(3,15)$. Consequently, an additional assumption is that the pathogen cannot jump shires and can only spread into a neighboring shire.

Implementation. Spread starts $\left(S_{s}\right)$ from the source shire with an initial amount of pathogen inoculum $\left(S_{a}\right)$. After initial establishment of $T$. indica, the pathogen population will increase in size at a rate dependent on its net reproductive rate $(R)$. For pathogenic fungi like $T$. indica, the parameter $R$ measures the average number of secondary cases of infection generated by one primary case, in a susceptible host population. The intrinsic population growth rate $\left(S_{p}\right)$ is equivalent to $\log _{\mathrm{e}} R(7)$. Biological data on the population growth dynamics of $T$. indica was not available so two estimates of $S_{p}$ were used to simulate population growth and spread. They were (i) $S_{p 1}=0.69$, a doubling in area of infected crop at each time interval, and (ii) $S_{p 2}=2.30$, a 10 -fold increase in area of infected crop at each time interval (Table 2). T. indica population growth and spread is calculated with a logistic growth function (10):

$$
d T_{a i} / d t=S_{p} \cdot T_{a i}\left(1-T_{a i} / A_{p}\right)
$$

where $d T_{a i} / d t=$ the rate of change in area of infected crop in the shire, $S_{p}=$ the intrinsic population growth rate of the pathogen $\left(\log _{\mathrm{e}} R\right), T_{a i}=$ the total area of infected crop in the shire, and $A_{p}=$ the total area planted to wheat in the shire (carrying capacity).

The logistic growth function was chosen because it provides a simple description of density-dependent population growth (10). The total area under wheat cultivation in WA $\left(A_{t}\right)$ is approximately $3,900,000$ ha. Data on the area planted to wheat $\left(A_{p}\right)$ for each shire were collated from the Australian Bureau of Statistics, Agricultural Census (1998 to 1999).

The probability of spread starting $\left(p_{s}\right)$ in any category 2 shire increases as the area of crop infected by the pathogen in the category 1 shire increases, as well as any other category 2 shires that already have infected crops that border the shire in question. It is also dependent on the climatic suitability of each shire. Climatic suitability for $T$. indica establishment and spread is represented by the likelihood that a shire receives at least three suitable rain events over a 2-day period during the month of anthesis of the host crop $\left(p_{s r}\right)(15,22)$. A suitable rain event re- quires a minimum of $3 \mathrm{~mm}$ of rain on any of the 2 days, and a minimum total of $10 \mathrm{~mm}$ over the 2 days. This data was obtained from the rainfall modeling software Australian Rainman V 3.3 (The Department of Agriculture, Western Australia). In general, establishment and spread of $T$. indica is favored by climatic conditions in the central and western areas of the WA wheatbelt. Eastern areas are usually too hot and dry and southern areas are usually too cold or wet (24).

Implementation. The probability of spread starting $\left(p_{s}\right)$ after an incursion is calculated with a binomial function:

$$
p_{s}=\left\{1-\left[1-\left(p_{c}\right)\right]^{\wedge A i 1+A i 2 \ldots . .+A i 1 x}\right\} S
$$

where $A_{i 1}+A_{i 2}+A_{i 1 x}=$ the total area of contaminated farmland in all shires that border the shire in question, $p_{c}=$ constant, and $S=$ climate suitability (takes on the value of 0 or 1 depending on whether or not the climate in a shire is suitable for pathogen development and spread). This output was generated using the Monte-Carlo function in STELLA. The probability values for suitable climate in each shire were determined from earlier research (24).

Process 4-Detection and containment. It is assumed that there are two ways in which $T$. indica can be detected. First, the farmer may detect the disease in the heads of the wheat crop during harvest, assuming that the farmer visually inspects the crop. Whether or not they detect the disease is dependent on the awareness of the farmer and on the proportion of the crop that is infected. However, it needs to be remembered that infection levels are usually very low and harvesting is often done by subcontractors and at night. Based on this, the likelihood of farmer detection would be very low.

Secondly, the pathogen can be detected as part of routine inspection carried out at grain delivery facilities by The Department of Agriculture Western Australia through Cooperative Bulk Handling. Inspection may also be carried out by private consultants or by a pathology laboratory when samples of grain are sent for further analysis. The current detection method used in WA and the United States is a spore sieving technique used to separate individual spores for microscopic examination (6). Using this technique, detection reliability for $T$. indica is $100 \%$ at a contamination level of five teliospores per $50 \mathrm{~g}$ of wheat sample (19). This means that if sufficient resources were available to sample every hectare of wheat, the probability of detection would be close to

TABLE 1. Parameters used to model the risk of Tilletia indica entering (process 1) and establishing (process 2) for four separate pathways into Western Australia

\begin{tabular}{lcc}
\hline Parameter (variable) & Units & $\begin{array}{c}\text { Parameter } \\
\text { settings }\end{array}$ \\
\hline Bulk grain imports from affected regions $\left(n_{i}\right)$ & $\mathrm{kg}$ & 672 \\
Proportion grain infected and $\left(p_{i}\right)$ & $\%$ & 0.0004 \\
Proportion missed by quarantine $\left(p_{m}\right)$ & $\%$ & 0.1 \\
Proportion that establish in wheat crop $\left(p_{c}\right)$ & $\%$ & 0.5 \\
Proportion transported to wheat farms $\left(p_{f}\right)$ & $\%$ & 0.5 \\
Straw imports from affected regions $\left(n_{2}\right)$ & $\mathrm{kg}$ & 19 \\
Proportion straw infected $\left(p_{i 2}\right)$ & $\%$ & 0.001 \\
Proportion missed by quarantine $\left(p_{m 2}\right)$ & $\%$ & 0.1 \\
Proportion that establish in wheat crop $\left(p_{c 2}\right)$ & $\%$ & 0.5 \\
Proportion transported to wheat farms $\left(p_{f 2}\right)$ & $\%$ & 0.5 \\
Machinery imports from affected regions $\left(n_{3}\right)$ & Machines & 50 \\
Proportion machines contaminated $\left(p_{i 3}\right)$ & $\%$ & 0.001 \\
Proportion missed by quarantine $\left(p_{m 3}\right)$ & $\%$ & 0.1 \\
Proportion that establish in wheat crop $\left(p_{c 3}\right)$ & $\%$ & 0.5 \\
Proportion transported to wheat farms $\left(p_{f 3}\right)$ & $\%$ & 0.1 \\
Travelers from affected regions $\left(n_{4}\right)$ & People & 1,000 \\
Proportion travelers with contaminated goods $\left(p_{i 4}\right)$ & $\%$ & 0.001 \\
Proportion missed by quarantine $\left(p_{m 4}\right)$ & $\%$ & 0.01 \\
Proportion that establish in wheat crop $\left(p_{c 4}\right)$ & $\%$ & 0.1 \\
Proportion transported to wheat farms $\left(p_{f 4}\right)$ & $\%$ & 0.8 \\
\hline
\end{tabular}




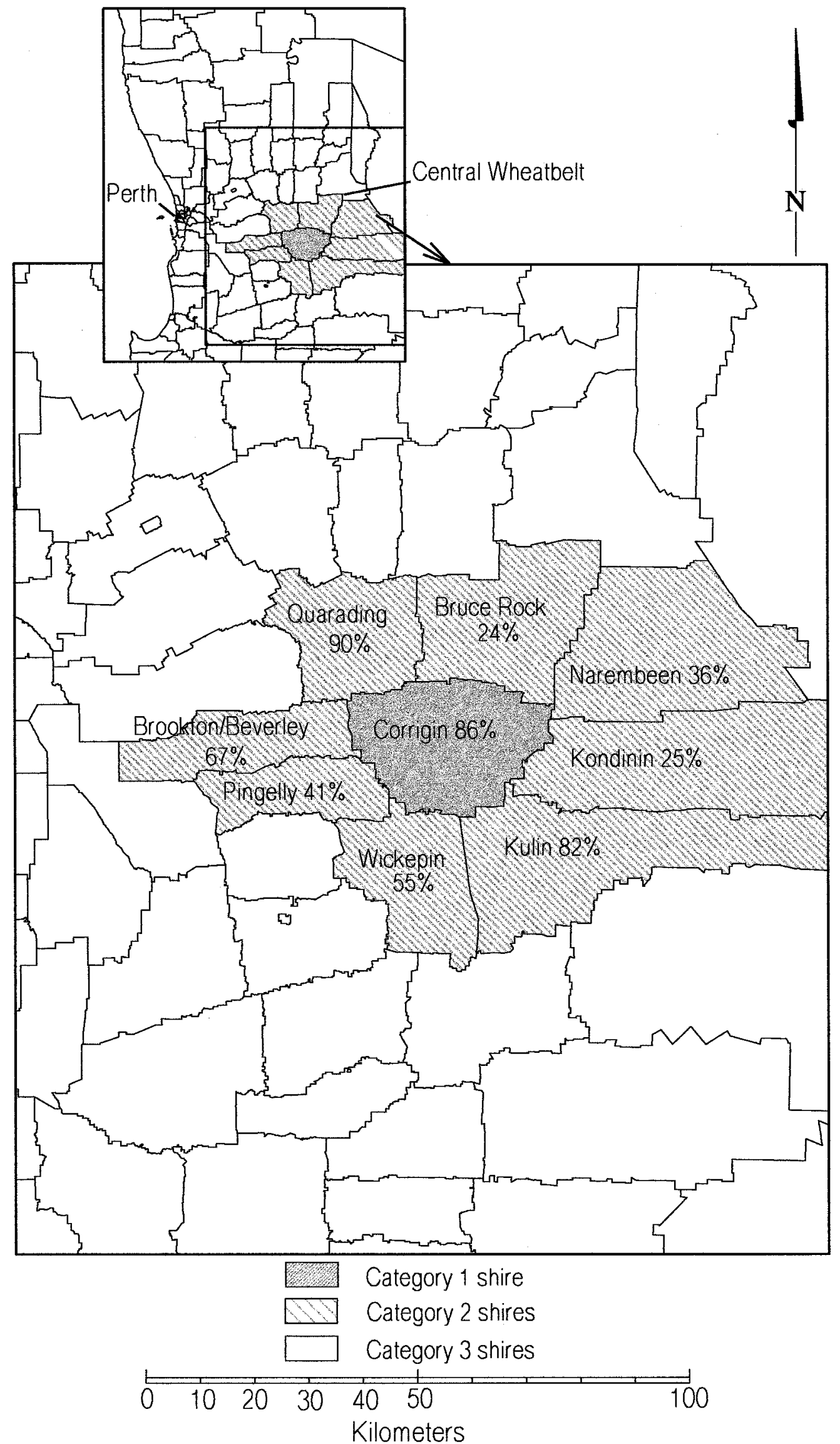

Fig. 1. Shire map and climatic suitability for Tilletia indica for part of the Western Australian wheatbelt. Percent values represent the probability of suitable climatic conditions for disease establishment (24). Infection begins in the category 1 shire before spreading into category 2 and 3 shires. Data on the area planted to wheat and crop yield in each shire, as well crop value, were collated from the Australian Bureau of Statistics, Agricultural Census (1998 to 1999). 
$100 \%$. It is most unlikely that sufficient resources for this level of surveillance would be available, so detection is dependent on the number of samples examined, which in turn is dependent on the funds available for examining samples.

Implementation. The total number of detections $\left(D_{t}\right)$ at each time interval for each shire is calculated by adding the number of detections made by farmers $\left(D_{f}\right)$ with the number of detections made by agricultural officers $\left(D_{a}\right)$.

$$
D_{t}=D_{f}+D_{a}
$$

where $D_{f}$ represents the mean number of detections by farmers and is determined by multiplying the probability of farmer detection $\left(p_{f}\right)$ by the area of crop infected by the disease $\left(A_{i}\right)$ (Table 3$)$. The probability of detection by farmers has been set at $1 \times 10^{-7}$, because it is almost impossible to detect the disease visually (1). $D_{f}$ is chosen from Poisson $\left(D_{f}\right)$ at each time interval. $D_{a}=$ the mean number of detections by agricultural officers and is expressed as

$$
D_{a}=\left[A_{i} /\left(A_{p}-A_{d t}\right)\right] \cdot A_{s}
$$

where $A_{i}=$ area of infected crop in that shire, $A_{p}=$ the total area planted to wheat in the shire, $A_{d t}=$ the total area of crop that has been detected as infected by the pathogen, and $A_{s}=$ the area that has been searched/sampled for the pathogen.

As the area of infected crop increases so does the probability of detection (Table 3 ). $D_{a}$ is chosen from Poisson $\left(D_{a}\right)$ at each time interval.
It is assumed that each shire receives a base amount of sampling funds $\left(M_{b}\right)$ from a pool of total sampling funds $\left(M_{t s}\right)$, in which the amount allocated is proportional to the size of the shire $\left(A_{s f}\right)$. If the pathogen is detected, additional funds are allocated $\left(M_{a}\right)$ to shires and divided into funds for containment $\left(M_{e}\right)$ and funds for further searching $\left(M_{s}\right)$. Within each shire, the pool of resources for disease management is divided between eradication $\left(A_{d}\right)$ and searching for other areas of infected crop $\left(A_{s}\right)$ (disinfection may include quarantine of the contaminated farmland for the required period). The rate of $A_{d}$ and $A_{s}$, after initial detection, is governed by the total amount of additional funding $\left(M_{a}\right)$ available to quarantine and containment, and by the cost of disinfection $\left(C_{d}\right)$ and the cost of searching $\left(C_{s}\right)$. Containment of contaminated crops that have been detected takes priority over searching for other infected crops, although a small portion of the total resources is maintained for additional ongoing costs $\left(C_{o}\right)$ (Table 4).

The model framework has been programmed such that the category 1 shire receives a portion $\left(p_{1}\right)$ of the $M_{a}$, category 2 shires share a portion $\left(p_{2}\right)$ of the $M_{a}$, and category 3 shires split the remaining portion $\left(p_{3}\right)$ of the $M_{a}$. If the pathogen has only been detected in the category 1 shire, that shire still receives its initial portion $\left(p_{1}\right)$ of the $M_{a}$. If the disease is also detected in a category 2 shire, the category 1 shire and the category 2 shires share the combined $p_{1}$ and $p_{2}$ of the $M_{a}$. If the disease is detected in all category shires, then the $M_{a}$ is divided equally among shires with infected crops (Fig. 1). Where the funds are shared, the amount received by each shire is proportional to the area planted to wheat in that shire $\left(A_{p}\right)$. Early detection and disinfection increases the

\begin{tabular}{|c|c|c|}
\hline Parameter (variable) & Units & Model formula and parameter setting \\
\hline Corrigin $\left(A_{p 1}\right)$ & ha & 82,000 \\
\hline Total area under wheat cultivation in Western Australia $\left(A_{t}\right)$ & ha & $A_{p 1}+A_{p 2}+\ldots . A_{p 10}(=$ approx. $3,900,000$ ha $)$ \\
\hline Spread start $\left(S_{s}\right)$ in category 2 shires & ha/week & If Monte-Carlo $\left[\operatorname{Pct}\left(p_{s}\right)\right]>0.5$, then $S_{a}$ else 0 \\
\hline Establishment $(E)$ & ha/week & $S_{s}$ \\
\hline Start amount $\left(S_{a}\right)$ & ha & 0.1 \\
\hline Area of infected crops undetected $\left(A_{i}\right)$ & ha & $A_{i}(t-d t)+\left(S_{p}+E-\mathrm{P}\right) \cdot d t \quad$ Initial $A_{i}=0$ \\
\hline Increase in area infected $\left(d T_{a i 1} / d t\right)$ & ha/week & $S_{p}^{P} \cdot T_{a i 1} \cdot\left(1-T_{a i 1} / A_{p 1}\right)$ \\
\hline Intrinsic rate of population growth $\left(S_{p}\right)$ & $\%$ & 0.69 or 2.31 \\
\hline Probability spread $\left(p_{s}\right)$ & $\%$ & $\left\{1-\left[1-\left(p_{c}\right)\right]^{\wedge} A_{i 1}+A_{i 2}+\ldots \ldots A_{i 1 x}\right\} \cdot S$ \\
\hline Probability constant $\left(p_{c}\right)$ & $\%$ & 0.00001 \\
\hline Total area of infected crops $\left(T_{a i}\right)$ & ha/week & $T_{d}+A_{i}$ \\
\hline Climate suitability $(S)$ & $\%$ & 0.86 \\
\hline
\end{tabular}

TABLE 2. Parameters and formulas used for modeling climatic suitability and spread of Tilletia indica in the category 1 shire (process 3 )

\begin{tabular}{|c|c|c|}
\hline Parameter (variable) & Units & Model formula and parameter setting \\
\hline Total mean detections $\left(D_{t}\right)$ & ha & $D_{a}+D_{f}$ \\
\hline Expected farmer detections $\left(D_{f}\right)$ & ha & $p_{f} \cdot A_{i}$ \\
\hline Expected agricultural officer detections $\left(D_{a}\right)$ & $\% /$ ha/week & {$\left[A_{i} /\left(A_{p}-A_{d t}\right)\right] \cdot A_{s}$} \\
\hline Random probability of detection $\left(p_{f}\right)$ & $\%$ & 0.0000001 \\
\hline Area planted to wheat $\left(A_{p}\right)$ & ha & Variable depending on the shire \\
\hline Shire 1 area detected $(t)\left(A_{d t}\right)$ & ha & $A_{d t}(t-d t)+\left(D_{t}-A_{d}\right) \cdot d t \quad$ Initial $A_{d t}=0$ \\
\hline Area disinfected $\left(A_{d}\right)$ & ha & $M_{d} / C_{d}$ \\
\hline Area searched $\left(A_{s}\right)$ & ha & $M_{s} / C_{s}$ \\
\hline Base funds $\left(M_{b}\right)$ & $\$$ & $M_{t s} \cdot A_{s f}$ \\
\hline Total base sampling funds for WA $\left(M_{t s}\right)$ & $\$$ & Variable (100,000 to 1 million) \\
\hline Shire area fraction $\left(A_{s f}\right)$ & Fraction & $A_{p} / A_{t}$ \\
\hline Additional funding for containment in WA $\left(M_{a}\right)$ & $\$$ per annum & Variable $(1,5$, and 10 million $)$ \\
\hline Cost per hectare disinfected $\left(C_{d}\right)$ & $\$$ & 25 \\
\hline Cost per hectare searched $\left(C_{s}\right)$ & $\$$ & 25 \\
\hline Containment funds for category 1 shires $\left(M_{e 1}\right)$ & $\$$ & If $D_{t}=0$, then $M_{b}$ else $M_{b}+\left(p_{m} \cdot M_{a}\right)$ \\
\hline Containment funds for category 2 shires $\left(M_{e 2}\right)$ & $\$$ & If $D_{t}=0$, then $M_{b}$ else $M_{b}+\left(p_{m} \cdot M_{a} \cdot A_{s f 2}\right)$ \\
\hline Search funds $\left(M_{s}\right)$ & ha & $M_{e}-M_{d}$ \\
\hline Disinfection funds $\left(M_{d}\right)$ & $\$$ & $\operatorname{Min}\left(D_{t} \cdot C_{d} \cdot M_{e}\right) \times 0.9$ \\
\hline Proportion of $M_{a}$ to a category 1 shire $\left(p_{1}\right)$ & Fraction & Variable $($ default $=0.33)$ \\
\hline Proportion of $M_{a}$ to a category 2 shire $\left(p_{2}\right)$ & Fraction & Variable $($ default $=0.33)$ \\
\hline Proportion of $M_{a}$ to a category 3 shire $\left(p_{3}\right)$ & Fraction & Variable $($ default $=0.34)$ \\
\hline
\end{tabular}

TABLE 3. Parameters and formulas used to model detection and containment of Tilletia indica in Western Australia (WA) (process 4) 
likelihood of containment because the area of infected crop and the rate of spread are reduced more quickly. Parameter values and model formula are described in Table 3.

Process 5-Economic impact. Even though T. indica has not been detected in WA, financial losses are already incurred in WA through costs associated with quarantine administration, research (such as this research project, or breeding programs), and disease surveillance. This is due to World Trade Organization guidelines that require scientific justification, in the form of quantitative sampling, in order to maintain Australia's area freedom status for Karnal bunt.

If $T$. indica were to be detected in WA, without it also being detected in countries that import Australian wheat, numerous additional costs would fall on the grains industry. Additional costs to the farmer include costs of a reduction in crop yield, an increase in the cost of production (i.e., application of fungicides), an increase in export restrictions, and a loss of seed/ grain export markets. Additional costs to government include increases in quarantine administration, research, and testing/sampling costs (15).

Other economic considerations also include compensation to farmers and whether or not the wheat crop could be sold as a salvage crop (e.g., as animal feed). For example, U.S. regulations in 1997 to 1998 state that growers, handlers, and seed companies are eligible for a maximum of US\$1.80 per bushel (1 bushel of wheat equals $27.3 \mathrm{~kg}$ ) of wheat found to contain $T$. indica in the first season of regulation and US\$0.60 per bushel in subsequent seasons. Owners of grain storage facilities receive up to $50 \%$ of the direct cost of decontamination of a grain storage facility, but compensation does not exceed US\$20,000 per facility. Compensation for mill feed treatment is at the rate of US $\$ 35.00$ per short ton of mill feed. Compensation cost equals estimated market price of uninfected wheat minus the salvage value of the infected crop. Should T. indica be detected in Australia, additional costs incurred by farmers could be off set by a compensation package, although the net cost to the industry would not change.

Implementation. The model is implemented such that if a shire is free of $T$. indica then the ongoing costs to farmers $\left(C_{o f}\right)$ is equivalent to any fungicide costs per hectare multiplied by the area planted to wheat in that shire $\left(A_{p}\right)$. The ongoing costs to government $\left(C_{o g}\right)$ is equivalent to

$$
C_{o g}=\left(C_{r}+C_{s t}+C_{a}\right) \cdot A_{p}
$$

where $C_{r}=$ research costs per hectare, $C_{s t}=$ sampling/testing costs per hectare, and $C_{a}=$ administration costs per hectare.

If the pathogen is detected in a shire, then the total costs to farmers $\left(C_{t f}\right)$ is equivalent to

$$
C_{t f}=C_{o_{\mathrm{f}}}+\left[\left(C_{e r}+C_{l s m}+C_{l c v}\right) \cdot A_{p}\right]-C_{m p}
$$

where $C_{o f}=$ ongoing farmer costs (fungicides), $C_{e r}=$ cost per hectare of export restrictions, $C_{l s m}=$ costs per hectare associated with a loss in seed markets, $C_{l c v}=$ costs per hectare associated with a loss in crop value, and $C_{m p}=$ compensation per hectare.

Currently, the WA State Government and the wheat industry do not have compensation arrangements for Karnal bunt. If a compensation package $\left(C_{m p}\right)$ were set up to promote farmer awareness and reporting of potential Karnal bunt outbreaks, $C_{m p}$ should offset $C_{t f}$.

If the disease is detected, the total costs to government $\left(C_{t g}\right)$ are equivalent to

$$
C_{t g}=C_{o g}+\left(F_{a} \cdot A_{p}\right)+C_{m p}
$$

where $C_{o g}$ and $C_{m p}$ are as described previously, and $F_{a}=$ additional funds per hectare allocated by government in the event of an infection.

\begin{tabular}{|c|c|c|}
\hline Parameter (variable) & Units & Model formula and parameter settings \\
\hline Ongoing costs to farmer $\left(C_{o f}\right)$ & $\$$ & $C_{d} \cdot A_{p}$ \\
\hline Ongoing costs to government $\left(C_{o g}\right)$ & $\$$ & $\left(C_{r}+C_{a}+C_{t}\right) \cdot A_{p}$ \\
\hline Total cost to farmer if detected $\left(C_{t f}\right)$ & $\$$ & $C_{o f}+\left[\left(C_{e r}+C_{l s m}+C_{l c v}\right) \cdot A_{p}\right]-C_{m p}$ \\
\hline Cost of fungicide $\left(C_{d}\right)$ & $\$ /$ ha & 1.00 \\
\hline Cost of research $\left(C_{r}\right)$ & $\$ /$ ha & 0.03 \\
\hline Cost of administration $\left(C_{a}\right)$ & $\$ /$ ha & 0.04 \\
\hline Cost of sampling/testing $\left(C_{t}\right)$ & $\$ /$ ha & 0.45 \\
\hline Loss in crop value $\left(C_{l c v}\right)$ & $\$ /$ ha & 100 \\
\hline Gross value of wheat crop $\left(F_{g c v}\right)$ & $\$$ & If $D_{t}=0$, then $\left(A_{p} \cdot Y \cdot C_{v}\right)-C_{o f}$ else $\left[A_{p} \cdot\left(Y-Y_{l}\right) \times S_{v}\right]-C_{t f}$ \\
\hline Compensation $\left(C_{m p}\right)$ & $\$ /$ ha & 0 \\
\hline Additional funding if detected $\left(F_{a}\right)$ & $\$ /$ ha & $M_{a} / A_{t}$ \\
\hline Yield loss $\left(Y_{l}\right)$ & $\$ /$ ha & 0.1 \\
\hline Salvage value $\left(S_{v}\right)$ & \$/tonne & 40 \\
\hline Crop yield $(Y)$ & tonnes/ha & (Variable for each shire) approx. 1.5 \\
\hline
\end{tabular}

TABLE 4. Parameters and formulas used to model the potential economic impact of Tilletia indica in Western Australia (process 5) assuming it successfully enters, establishes, and spreads

TABLE 5. Table listing the mean number of entries per year and establishments per year ( \pm standard deviation) under current conditions; and after the proportion of contaminated goods missed by quarantine $\left(p_{m}\right)$ is reduced by $50 \%$ a

\begin{tabular}{lccccc}
\hline Rank & Import & Entries/year & Establishments/year & $\begin{array}{c}\text { Entries/year after } \\
\text { 50\% decrease in } p_{m}\end{array}$ & $\begin{array}{c}\text { Establishments/year after } \\
50 \% \text { decrease in } p_{m}\end{array}$ \\
\hline 1 & Grain & $0.023 \pm 0.017$ & $0.009 \pm 0.009$ & $0.017 \pm 0.014$ & $0.005 \pm 0.007$ \\
2 & Travelers & $0.011 \pm 0.009$ & $0.004 \pm 0.003$ & $0.003 \pm 0.006$ & $0 \pm 0$ \\
3 & Machinery & $0.005 \pm 0.005$ & $0.001 \pm 0.003$ & $0.002 \pm 0.005$ & $0.001 \pm 0.003$ \\
4 & Straw & $0.004 \pm 0.007$ & $0.001 \pm 0.002$ & $0.001 \pm 0.003$ & 0 \\
Total & All imports & $0.042 \pm 0.039$ & $0.015 \pm 0.018$ & $0.023 \pm 0.028$ & $0.006 \pm 0.011$ \\
\hline
\end{tabular}

${ }^{\mathrm{a}} p_{m}=$ the proportion of contaminated goods that enter the country that are missed by quarantine. 
The gross value of the wheat crop to the farmer $\left(F_{g c v}\right)$ if $T$. indica is not present is equivalent to

$$
F_{g c v}=\left(A_{p} \cdot Y \cdot \mathrm{C}_{v}\right)-C_{o f}
$$

where $A_{p}$ and $C_{o f}$ are as described above, $Y=$ yield or tonnes per hectare of wheat for that shire, and $C_{v}=$ the crop value per tonne. Data for $Y$ and $C_{v}$ for each shire are available through the Australian Bureau of Statistics, Agricultural Census (Table 4).

If $T$. indica has been detected in a shire, then it is assumed that all wheat from that shire will be quarantined and can only be sold as a salvage crop. In this case,

$$
F_{g c v}=\left[A_{p} \cdot\left(Y-Y_{l}\right) \cdot S_{v}\right]-C_{t f}
$$

where $Y_{l}=$ crop yield loss per hectare due to the disease, $S_{v}=$ the salvage value per tonne for that year, and $C_{t f}=$ the total cost to farmers if Karnal bunt is detected (Table 4). For modeling purposes, the value for $F_{g c v}$ is currently discounted at a rate of $7 \%$ per annum.

\section{RESULTS AND DISCUSSION}

Model 1-Risk of pathogen entry and establishment. Estimates for the likelihood of $T$. indica entry and establishment are a function of the mathematical relationships described previously. The model was set on a 50-year cycle and run 100 times. Output was interpreted in terms of the mean probability that an event occurs each year (entry or establishment) \pm the average deviation. Table 5 lists the respective probabilities of entry and establishment for $T$. indica into WA for each of the four pathways modeled.

Based on the assumptions adopted, the results of the model indicate that entry and establishment of the disease will most likely result from imports of bulk grain. There will be on average $0.023 \pm 0.017$ entries per year, which is equal to one entry every 50 years. The average number of establishments per year is equal to $0.009 \pm 0.009$, which is about one establishment event every 100 years (Table 5). The total combined probability of entry and establishment of $T$. indica into WA, for all four pathways of arrival, is $0.042 \pm 0.039$ and $0.015 \pm 0.018$ events per year, re- spectively. This is equivalent to one entry every 25 years and one successful establishment every 67 years.

Sensitivity analysis is particularly useful for justifying increases in funding for quarantine by making it possible to assess how increased surveillance could influence the final probability of pathogen entry and establishment. For example, if it is assumed that funding for quarantine inspection is increased such that the probability of contaminated goods being missed decreases by $50 \%$ for each pathway, then the total combined probability of entry and establishment is reduced to $0.023 \pm 0.028$ and $0.006 \pm 0.011$ events per year, respectively (Table 5). This is about one entry every 50 years and less than one establishment every 100 years. This may be considered an appropriate risk management option if one establishment or less every 100 years is considered an acceptable level of risk.

Sensitivity analysis also allows decisions to be made with respect to critical levels/numbers of imports of particular goods from certain countries. For example, risk management guidelines may suggest that the probability of entry and establishment of a disease should not exceed more than one event every 100 years. Sensitivity analysis can be used in the risk assessment process to help make risk management decisions that ensure the probability of establishment remains below the perceived ideal or critical level.

A good example of how easily a pest can enter is new agricultural machinery such as harvesters, which have been field tested before being imported. Despite tight regulations regarding the importation of any farm machinery, a new machine recently imported into Australia was found by AQIS to be contaminated with $0.5 \mathrm{~kg}$ of wheat straw and seed. In addition, a dealer in agricultural machinery, located in a wheat-growing region in New South Wales, Australia, found approximately $3 \mathrm{~kg}$ of wheat straw, weeds, seeds, and soil in another machine. The fact that the second discovery was for a machine that had already been transported to a wheat-growing region highlights the potential for a pathogen to reach a host crop.

Model 2-Pathogen spread, detection, containment, and economic impact. The two rates of spread were modeled in conjunction with nine different management regimes to simulate spread, detection, and containment of Karnal bunt. The nine management regimes reflect different amounts of total base sampling

TABLE 6. Time until first detection and total area of wheat infected (hectares) with Tilletia indica in Western Australia ( \pm standard deviation) in categories 1,2 ,

\begin{tabular}{|c|c|c|c|c|c|c|c|}
\hline \multirow[b]{2}{*}{ SMR } & \multirow[b]{2}{*}{$S_{p}{ }^{\mathrm{a}}$} & \multirow[b]{2}{*}{$M_{b}{ }^{\mathrm{b}}$} & \multirow[b]{2}{*}{$M_{a}{ }^{\mathrm{c}}$} & \multirow{2}{*}{$\begin{array}{c}\text { Time until first } \\
\text { detection (years) }\end{array}$} & \multicolumn{3}{|c|}{ Area of infected crop $\left(\text { ha } \times 10^{3}\right)^{\mathrm{d}}$} \\
\hline & & & & & Category 1 shires & Category 2 shires & Category 3 shires \\
\hline 1 & 1 & 1 & 1 & $10.85 \pm 1.98$ & $80.3 \pm 0.7$ & $446.0 \pm 97.4$ & $1,340.0 \pm 131.0$ \\
\hline 2 & 1 & 2 & 1 & $8.85 \pm 2.28$ & $79.4 \pm 2.1$ & $434.0 \pm 100.7$ & $1,150.0 \pm 1,238.0$ \\
\hline 3 & 1 & 3 & 1 & $7.20 \pm 1.84$ & $79.5 \pm 2.0$ & $434.0 \pm 94.5$ & $1,280.0 \pm 1,270.0$ \\
\hline 4 & 1 & 1 & 2 & $10.50 \pm 2.55$ & $39.3 \pm 38.1$ & $174.0 \pm 203.4$ & $471.0 \pm 744.2$ \\
\hline 5 & 1 & 2 & 2 & $9.20 \pm 1.94$ & $57.2 \pm 28.3$ & $259.0 \pm 216.6$ & $912.0 \pm 1,192.0$ \\
\hline 6 & 1 & 3 & 2 & $7.45 \pm 3.43$ & $14.3 \pm 23.5$ & $88.2 \pm 144.9$ & $306.0 \pm 530.0$ \\
\hline 7 & 1 & 1 & 3 & $11.15 \pm 2.16$ & $1.6 \pm 3.1$ & $7.1 \pm 14$ & $32.5 \pm 64.5$ \\
\hline 8 & 1 & 2 & 3 & $9.60 \pm 1.64$ & $0 \pm 0$ & $0 \pm 0$ & $0 \pm 0$ \\
\hline 9 & 1 & 3 & 3 & $7.45 \pm 1.54$ & $0 \pm 0$ & $0 \pm 0$ & $0 \pm 0$ \\
\hline 10 & 2 & 1 & 1 & $7.30 \pm 0.66$ & $85.0 \pm 5.1$ & $643.0 \pm 26.7$ & $3,570.0 \pm 246.6$ \\
\hline 11 & 2 & 2 & 1 & $6.00 \pm 0.6$ & $85.7 \pm 4.8$ & $640.0 \pm 28.0$ & $3,590.0 \pm 228.6$ \\
\hline 12 & 2 & 3 & 1 & $4.45 \pm 0.99$ & $86.1 \pm 4.7$ & $641.0 \pm 28.5$ & $3,560.0 \pm 270.7$ \\
\hline 13 & 2 & 1 & 2 & $6.30 \pm 1.13$ & $85.5 \pm 5.5$ & $638.0 \pm 31.7$ & $3,530.0 \pm 306.4$ \\
\hline 14 & 2 & 2 & 2 & $6.25 \pm 0.88$ & $85.7 \pm 5.4$ & $635.0 \pm 31.3$ & $3,530.0 \pm 284.3$ \\
\hline 15 & 2 & 3 & 2 & $5.00 \pm 0.90$ & $86.3 \pm 5.6$ & $638.0 \pm 31.6$ & $3,540.0 \pm 302.8$ \\
\hline 16 & 2 & 1 & 3 & $6.15 \pm 1.04$ & $64.4 \pm 2.7$ & $495.0 \pm 196.1$ & $2,630.0 \pm 1,173.0$ \\
\hline 17 & 2 & 2 & 3 & $5.40 \pm 0.70$ & $60.2 \pm 32.4$ & $456.0 \pm 231.5$ & $2,460.0 \pm 1,485.0$ \\
\hline 18 & 2 & 3 & 3 & $5.20 \pm 1.10$ & $52.7 \pm 35.0$ & $394.0 \pm 266.7$ & $2,090.0 \pm 1,464.0$ \\
\hline
\end{tabular}
and 3 shires where calculations were made for $18 \mathrm{spread} / \mathrm{management} \mathrm{regimes} \mathrm{(SMR)}$

a $S_{p} 1=0.69$ or a doubling in population numbers, $S_{p} 2=2.30$ or a 10 -fold increase in population numbers.

${ }^{\mathrm{b}} M_{b} 1=\$ 100000, M_{b} 2=\$ 300000$, and $M_{b} 3=\$ 1,000,000$.

${ }^{c} M_{a} 1=\$ 1000000, M_{a} 2=\$ 5000000$, and $M_{a} 3=\$ 50,000,000$.

d The total area planted to wheat in Western Australia is $\approx 3.9$ million ha. Category 1 shires is $\approx 81,000$ ha, category 2 shires $\approx 650,000$ ha, and category 3 shires $\approx 3,300,000$ ha (Fig. 1). 

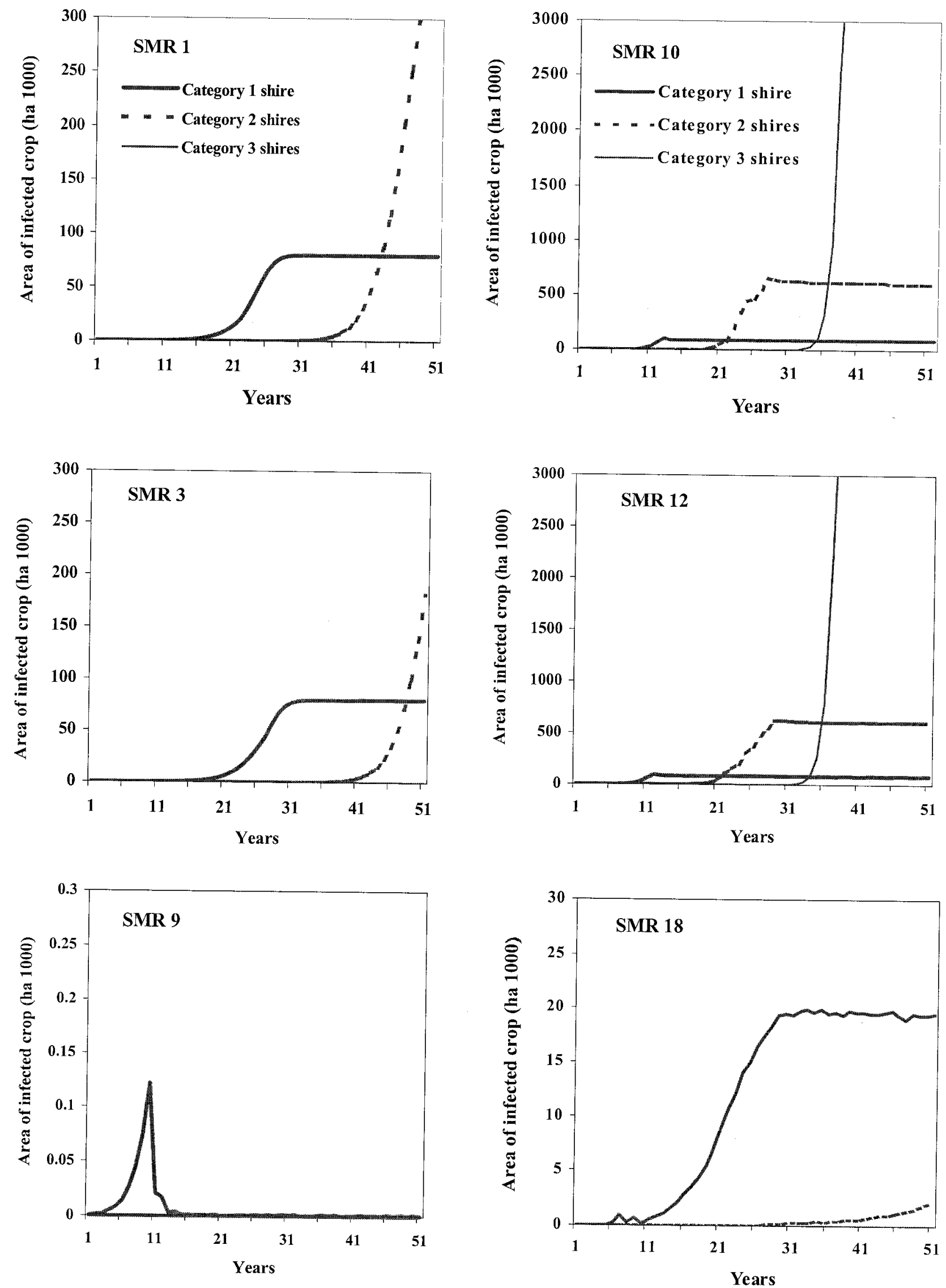

Fig. 2. Model examples of spread by Tilletia indica into category 1, 2, and 3 shires under different spread/management regimes (SMR). Explanation of the different SMR in Table 6. The figures on the left depict a doubling in area of infected crop each time interval, under three management regimes. The figures on the right depict a 10 -fold increase in area of infected crop each time interval, under the same three management regimes. 
funds $\left(M_{b}\right)$ and additional funding for containment $\left(M_{a}\right)$. The amounts of $M_{b}$ were (Australian [A]) A $\$ 100,000, \mathrm{~A} \$ 300,000$, and A $\$ 1,000,000$ per annum (p.a.); and the amounts of $M_{a}$ were $\mathrm{A} \$ 1,000,000, \mathrm{~A} \$ 5,000,000$, and $\mathrm{A} \$ 50,000,000$ p.a. (Table 6).

Results for $S_{p 1}$. When spread was equal to a doubling in area of infected crop each year $\left(S_{p 1}=0.69\right)$ the time until the disease was first detected in the category 1 shire varied from 10.5 to 11.2 years when the base sampling funds $\left(M_{b}\right)=1 ; 8.9$ to 9.6 years when the base sampling funds $\left(M_{b}\right)=2$; and 7.2 to 7.45 years when the base sampling funds $\left(M_{b}\right)=3$.

Any increase in $M_{b}$ or $M_{a}$ generally resulted in the pathogen being detected earlier and a delay in pathogen spread into either category 2 or category 3 shires (Fig. 2). When additional funding for sampling and containment $\left(M_{a}\right)$ was equal to $\mathrm{A} \$ 1,000,000$, spread to category 2 and category 3 shires was likely. The pathogen took approximately 19 years before it spread into the category 2 shires and up to approximately 43 years before it spread into category 3 shires. When additional funding was equal to A\$5,000,000 or greater, spread to category 2 and category 3 shires did not occur, i.e., the disease outbreak could be contained within the category 1 shire. Figure 2 depicts spread generated by the model for six different SMRs.

Results for $S_{p 2}$. When spread was equal to a 10 -fold increase in area of infected crop each year $\left(S_{p 2}=2.30\right)$ the time until the disease was first detected in the category 1 shire varied from 6.2 to 7.3 years when the base sampling funds $\left(M_{b}\right)=1 ; 5.4$ to 6.0 years when the base sampling funds $\left(M_{b}\right)=2$; and 4.5 to 5.2 years when the base sampling funds $\left(M_{b}\right)=3$.

When the additional funds for sampling and containment was less than $\mathrm{A} \$ 50,000,000$, the average time until spread into category 2 shires was approximately 10 years after initial infection, and the average time for spread into category 3 shires was approximately 22 years.

Spread of $T$. indica was contained within the category 1 shire only when the additional sampling funds $\left(M_{a}\right)=\mathrm{A} \$ 50,000,000$; although, in some years the disease spread into category 2 shires (Fig. 2). When the pathogen spread into category 2 shires, it took approximately 14 years after initial infection in the category 1 shire. On no occasion did the pathogen spread into category 3 shires (Fig. 2).

Overall, the results show that when the area of crop infected by the pathogen doubles each year, control is only possible if $M_{b}=$
$\mathrm{A} \$ 1,000,000$ and $M_{a}=\mathrm{A} \$ 50,000,000$. The overall trend is that higher levels of $M_{b}$ result in the disease being detected earlier (approximately 7 years after initial establishment compared with 11 years when spread is $S_{p}=1$; and 5 years after initial establishment compared with 6.5 years when $S_{p}=2$ ) (Table 6). Adequate funding generally results in outbreaks of the disease in the category 1 shire being detected earlier and kept at low levels such that the disease does not spread into either category 2 or category 3 shires. This can be achieved without increasing the additional funds used for containment. When the area of crop infected by the pathogen increases 10-fold each year, control is much less likely, with none of the management regimes effectively controlling spread.

Following the 1999 harvest in the United States, no spores of $T$. indica were detected. Based on the model presented in this paper, this may have been a result of successful containment following adequate funding for management and quarantine. For example, APHIS allocated over US\$3,000,000 annually to conduct national surveys to meet export certification requirements and define pestfree areas. These surveys were conducted each year following the first detected outbreak in 1996. Between 1996 and 1998, about 35,500 samples were examined for spores of $T$. indica across all wheat growing regions. In addition to the national survey, surveys were also carried out in regulated areas within the designated Karnal bunt quarantine zone. Regulated areas include districts where bunted kernels had previously been detected (Arizona), or areas where bunted seed was suspected to have been planted (California, New Mexico, and Texas). Based on 1996 plantings, the Karnal bunt quarantine zone covered an area of approximately 140,000 ha, of which $20 \%$ or 28,000 ha was considered contaminated. In regulated areas, 150 full-time staff and 230 temporary staff were deployed to help with preharvest sampling and other program activities. In 1999, 1,097 samples covering an area of approximately 18,300 ha were examined for $T$. indica, i.e., one sample for nearly every 17 ha of wheat.

Economic impact. The present value of wheat production in WA is approximately A $\$ 13,000$ million over the next 50 years (all values are discounted at a rate of $7 \%$ ). If $T$. indica were to establish in WA and spread at a rate equivalent to $S_{p 1}$, it could cost the industry about $\mathrm{A} \$ 1$ billion over the same period or between 7.6 to $9.6 \%$ of the current value of wheat production in the state. Alternatively, if the disease spread at a rate equivalent to $S_{p 2}$, and

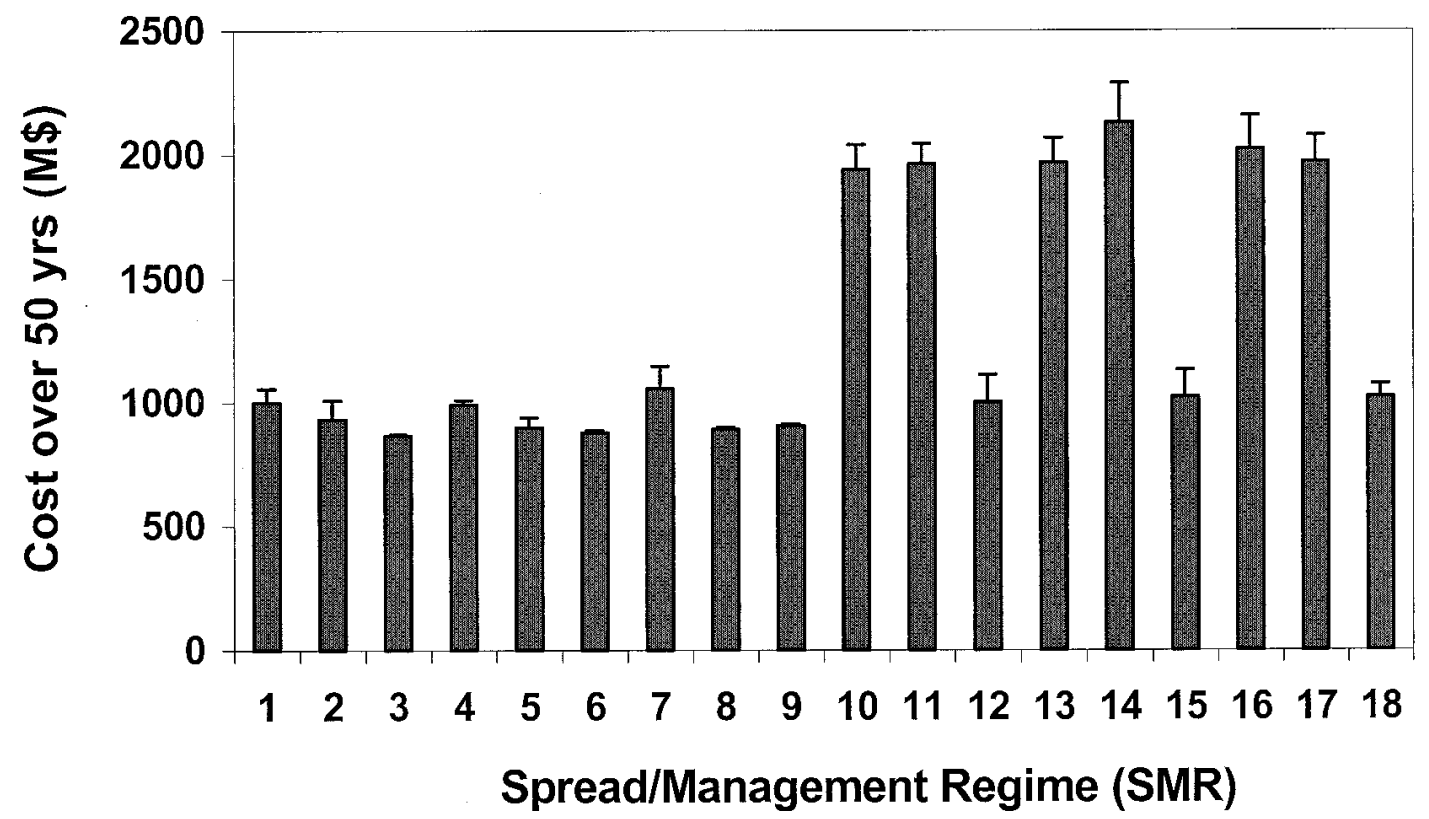

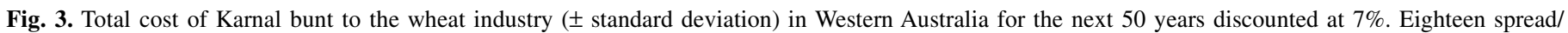
management regimes (SMR) have been simulated (Table 6). 
the minimum management regime was adopted, it could cost the industry as much as $\mathrm{A} \$ 2$ billion over the same period or between 21 to $24 \%$ of the current value of wheat production in the state. If the pathogen spreads at a rate equivalent to $S_{p 2}$, and funding was available for the most costly management regime, the overall costs could be maintained at around $\mathrm{A} \$ 1$ billion or $8 \%$ of the current value of wheat production in the state (Fig. 3).

These model results are comparable to estimates previously calculated by Murray and Brennan (15). They estimated that the cost of an incursion of $T$. indica to the WA wheat industry would be about A \$203 million annually or $17 \%$ of the total value of wheat production. This estimate was based on a 10-year average price for wheat of A $\$ 199$ per tonne. The key differences between the model of Murray and Brennan (15) and ours are that our model (i) reflects costs based on spread of the disease over a 50-year period, discounted at a rate of $7 \%$, with an average price of wheat for WA of $\mathrm{A} \$ 150$ per tonne, and (ii) is dynamic in that it incorporates spatial and temporal changes in spread due to climatic variation. For example, it may take up to 10 years before the disease is detected and the climate in some regions and years may not be suitable for T. indica sporulation and spread. The Murray and Brennan (15) calculation is static in that it does not consider changes in the rate of spread associated with climate variability. It is based on losses incurred by all regions that have suitable climate for the pathogen in any one year.

It is clear from the model that the cost of containment of $T$. indica is extremely high. Therefore, it would be appropriate to optimize the relative proportion of funds spent on barrier activities to minimize the likelihood of entry (model 1 results). In the event that the pathogen does enter WA, it would also be beneficial to optimize surveillance activities (sampling) based on the climatic suitability of each wheat producing shire to development and spread of $T$. indica (24).

Surveillance for $T$. indica in WA currently relies on the analysis of about 500 samples of wheat per annum collected from regional grain delivery facilities. Detection also depends on the vigilance of researchers, development officers, private consultants, seed companies, and others involved in agribusiness. This also includes farmer assessment for any of the visual symptoms of Karnal bunt. It is clear from this study that the current level of surveillance for T. indica in WA is insufficient to prove a reasonable prospect for containment if establishment were to occur. However, the resources provided by The Department of Agriculture Western Australia for Karnal bunt surveillance are considerably greater than any other state in Australia.

In summary, the aim of this research was to develop a risk assessment model that quantifies entry and establishment potential, estimates the rate of spread, incorporates containment, and calculates the likely economic impact of $T$. indica in WA. The results of model 1 indicate that the combined probability of entry and establishment of $T$. indica, for all pathways of entry, is about one entry every 25 years and one establishment every 67 years, and entry is most likely to occur through imports of bulk grain or fertilizer. Increases in quarantine funding could reduce the probability of entry to about one entry every 50 years and less than one establishment every 100 years. A primary problem that was realized during the development of model 1 was the lack of detailed data on the importation of products known to be hosts and potential pathways for the pathogen, in particular, data indicating reasons why certain imports were rejected. Future availability of detailed data would allow for further refinement of the model.

The results of model 2 indicate that, depending on the rate of spread of the pathogen and the amount of resources allocated to detection, the time until first detection could range from 4 to 11 years. This also had a direct effect on the potential economic impact, which ranged from 8 to $24 \%$ of the total value of wheat production in WA. There is a high probability of very low initial infection levels, especially if climatic conditions are not ideal. Detection within a couple of years of entry is only likely if sufficient resources are directed to baseline surveillance. Based on the current level of resources and sampling, if $T$. indica does establish in WA, it is likely to be present for several seasons before it is detected. Assuming suitable weather conditions prevail, efficient dispersal will make containment unlikely and quarantine of affected areas may be the only option. This may possibly enable the declaration of area freedom for regions not affected, for example, declare WA free from the disease if it is detected in the Eastern States or visa versa.

\section{ACKNOWLEDGMENTS}

We thank M. Stuart for advice on WTO provisions and Western Australian Quarantine Policy, G. Murray for helpful comments and discussions regarding the epidemiology of T. indica, and N. Stephenson for help in compiling and presenting the maps.

\section{LITERATURE CITED}

1. Agrawal, K., Yadav, V., Singh, T., and Singh, D. 1986. Occurrence and detection of Karnal bunt in wheat seed in Rajasthan. Indian J. Mycol. Plant Pathol. 16:290-291.

2. Beatie, B. R., and Biggerstaff, D. R. 1999. A wimp of a disease... but an irresistible political opportunity. Choices (Second Quarter) 14:4-8.

3. Bonde, M. R., Peterson, G. L., Schaad, N. W., and Smilanick, J. L. 1997. Karnal bunt of wheat. Plant Dis. 81:1370-1377.

4. Brennan, J. P., and Warham, E. J. 1990. Economic losses from Karnal bunt of wheat in Mexico. CIMMYT Economics Working Paper 90/02. International Maize and Wheat Improvement Center, Mexico, D.F.

5. Brennan, J. P., Warham, E. J., Byerlee, D., and Hernandez-Estrada, J. 1992. Evaluating the economic impact of quality reducing, seedborne diseases: Lessons from Karnal bunt of wheat. Agric. Econ. 6:345352.

6. Castro, C., Schaad, N. W., and Bonde, M. R. 1994. A technique for extracting Tilletia indica teliospores from contaminated wheat seeds. Seed Sci. Technol. 22:91-98.

7. Cousens, R., and Mortimer, M. 1995. Dynamics of Weed Populations. Cambridge University Press, Cambridge.

8. Crous, P. W., Van Jaarsveld, A. B., Castlebury, L. A., Carris, L. M., Frederick, R. D., and Pretorius, Z. A. 2001. Karnal bunt of wheat newly reported from the African continent. Plant Dis. 85:561.

9. Duran, R. 1972. Further aspects of teliospore germination in North American smut fungi. Can. J. Bot. 50:2569-2573.

10. Gillman, M., and Hails, R. 1997. An Introduction to Ecological Modeling: Putting Practice into Theory. Blackwell Science Ltd., Oxford.

11. Holmes, G. J., Jackson, L. F., and Perring, T. M. 1996. Imperial Valley conditions limit Karnal bunt in wheat. Calif. Agric. 51:29-33.

12. Jhorar, O. P., Mavi, H. S., Sharma, I., Mahi, G. S., Mathauda, S. S., and Singh, G. 1992. A biometeorological model for forecasting Karnal bunt disease of wheat. Plant Dis. Res. 7:204-209.

13. Mavi, H. S., Jhorar, O. P., Sharma, I., Singh, G., Mahi, G. S., Mathauda, S. S., and Aujla, S. S. 1992. Forecasting Karnal bunt disease of wheat-A meteorological method. Cereal Res. Commun. 20:67-74.

14. Mitra, M. 1931. Tilletia indica n. sp. A new bunt of wheat in India. Ann. Appl. Biol. 18:178-180.

15. Murray, G. M., and Brennan, J. P. 1998. The risk to Australia from Tilletia indica, the cause of Karnal bunt of wheat. Aust. Plant Pathol. 27:212-225.

16. Murray, G. M., Brennan, J. P., and Hare, R. A. 1996. Karnal bunt of wheat: Getting closer to Australia? Agric. Sci. 9:45-48.

17. Nagarajan, S., Aujla, S. S., Nanda, G. S., Sharma, I., Goel, L. B., Kumar, J., and Singh, D. V. 1997. Karnal bunt (Tilletia indica) of wheat-A review. Rev. Plant Pathol. 76:1207-1214.

18. Palm, M. E. 1999. Mycology and world trade: A review from the front line. Mycologia 91:1-12.

19. Peterson, G. L., and Bonde, M. R. 2000. Size-selective sieving for detecting teliospores of Tilletia indica in wheat seed samples. Plant Dis. 84:999-1007.

20. Sansford, C. 1998. Karnal bunt (Tilletia indica): Detection of Tilletia indica Mitra in the US: Potential risk to the UK and the EU. Pages 273302 in: Bunts and Smuts of Wheat: An International Symposium. V. S. Malik and D. E. Mathre, eds. NAPPO, Ottawa.

21. Smilanick, J. L., Prescott, J. M., Hoffman, J. A., Secrest, L. R., and Weise, K. 1989. Environmental effects on survival and growth of 
secondary sporidia and teliospores of Tilletia indica. Crop Prot. 8: 86-90.

22. Smiley, R. W. 1997. Risk assessment for Karnal bunt occurrence in the Pacific Northwest. Plant Dis. 81:689-692.

23. Smith, O. P., Peterson, G. L., Beck, R. J., Schaad, N. W., and Bonde, M. R. 1996. Development of a PCR-based method for identification of Tilletia indica, casual agent of Karnal bunt of wheat. Phytopathology $86: 115-122$.

24. Stansbury, C. D., and McKirdy, S. J. 2001. Forecasting climate suit- ability for Karnal bunt of wheat: A comparison of two meteorological methods. Australas. Plant Pathol. 30:1-12.

25. Stansbury, C. D., and Pretorius, Z. A. Modelling the potential distribution of Karnal bunt of wheat in South Africa. S. Afr. J. Plant Soil 18:159-168.

26. Vose, D. J. 1997. Risk analysis in relation to the importation and exportation of animal products. Contamination of animal products: Prevention and risks for animal health. Rev. Sci. Tech. Off. Int. Epizoot. 16:17-29. 